\title{
Niastella koreensis gen. nov., sp. nov. and Niastella yeongjuensis sp. nov., novel members of the phylum Bacteroidetes, isolated from soil cultivated with Korean ginseng
}

\author{
Hang-Yeon Weon, ${ }^{1}$ Byung-Yong Kim, ${ }^{2}$ Seung-Hee Yoo, ${ }^{2}$ \\ Seon-Young Lee, ${ }^{2}$ Soon-Wo Kwon, ${ }^{2}$ Seung-Joo Go ${ }^{2}$ \\ and Erko Stackebrandt ${ }^{3}$ \\ ${ }^{1}$ Applied Microbiology Division, National Institute of Agricultural Science and Technology, \\ Rural Development Administration, Suwon 441-707, Korea
}

Correspondence Soon-Wo Kwon swkwon@rda.go.kr
${ }^{2}$ Korean Agricultural Culture Collection (KACC), Microbial Genetics Division, National Institute of Agricultural Biotechnology, Rural Development Administration, Suwon 441-707, Korea

${ }^{3}$ Deutsche Sammlung von Mikroorganismen und Zellkulturen $\mathrm{GmbH}$, Mascheroder Weg $1 \mathrm{~b}$, D-38124 Braunschweig, Germany

Two novel strains, GR20-10 $0^{\top}$ and GR20-13 ${ }^{\top}$, were isolated from soil using R2A medium. The soil sample was collected from a field in the Yeongju region of Korea that was cultivated with Korean ginseng. Phylogenetic analysis based on 16S rRNA gene sequences indicated that these strains formed a cluster with several uncultured bacterial clones and with Flexibacter filiformis, Flexibacter sancti, Flexibacter japonensis, Cytophaga arvensicola and Flavobacterium ferrugineum (recently reclassified as Terrimonas ferruginea) in the phylum Bacteroidetes. The level of 16S rRNA gene sequence similarity between the two novel strains was $98.9 \%$. Isolates GR20-10 ${ }^{\top}$ and GR20-13 $3^{\top}$ showed the highest sequence similarities to Flexibacter japonensis IFO $16041^{\top}$ (91.8 and $91.9 \%$, respectively) and T. ferruginea ATCC $13524^{\top}$ (90.4 and $90.6 \%$, respectively). The whole-cell fatty acid profiles of the two isolates were similar and their major fatty acids were $15: 0$ iso, $17: 0$ iso $3-\mathrm{OH}$ and $15: 1$ iso $\mathrm{G}$. The major isoprenoid quinone of both strains was MK-7. The $\mathrm{G}+\mathrm{C}$ contents of GR20-10 $0^{\top}$ and GR20-13 ${ }^{\top}$ were $45 \cdot 8$ and $44 \cdot 3 \mathrm{~mol} \%$, respectively. DNA-DNA hybridization (57\% DNA-DNA hybridization value) and phenotypic data indicated that strains GR20-10 $0^{\top}$ and GR20-13 ${ }^{\top}$ each belong to a separate species. On the basis of phenotypic and phylogenetic data and genomic distinctiveness, strains GR20-10 ${ }^{\top}$ and GR20-13 ${ }^{\top}$ represent two novel species in a novel genus in the phylum Bacteroidetes; the names Niastella koreensis gen. nov., sp. nov. (the type species; type strain GR20-10 ${ }^{\top}=\mathrm{KACC} 11465^{\top}=\mathrm{DSM} 17620^{\top}$ ) and Niastella yeongjuensis sp. nov. (type strain GR20-13 ${ }^{\top}=$ KACC $11466^{\top}=$ DSM $17621^{\top}$ ) are proposed.
Within the phylum Bacteroidetes, the genera Flavobacterium, Flexibacter and Cytophaga are taxonomically heterogeneous. The taxonomic relationships amongst species within these genera have been largely resolved by phylogenetic analysis (Sly et al., 1999; Nakagawa \& Yamasato, 1993; Nakagawa et al., 2002). However, it is obvious that some species, for example Flexibacter filiformis, Flexibacter sancti, Flexibacter japonensis and Cytophaga arvensicola, form distinct lineages in the phylum Bacteroidetes (Sly et al., 1999) and thus

The GenBank/EMBL/DDBJ accession numbers for the 16S rRNA gene sequence of strains GR20-10 ${ }^{\top}$ and GR20-13 ${ }^{\top}$ are DO244077 and DQ244076, respectively. remain misclassified at the genus level. Flavobacterium ferrugineum, recently reclassified as Terrimonas ferruginea (Xie \& Yokota, 2006), was similarly misclassified.

In the course of a study of the bacterial diversity in fields cultivated with Korean ginseng (Panax ginseng C. A. Meyer), two novel strains, GR20-10 ${ }^{\mathrm{T}}$ and GR20-13 ${ }^{\mathrm{T}}$, were isolated in the Yeongju region, Korea. On the basis of phylogenetic analysis, these strains formed a distinct cluster closely related to Flexibacter filiformis, Flexibacter sancti, Flexibacter japonensis, Cytophaga arvensicola and T. ferruginea. The phenotypic and genotypic characterization of these two novel strains is described in this report. 
For observation of cell morphology by transmission electron microscopy (model 912AB; LEO) and phase-contrast microscopy (AXIO; Zeiss), cells were grown on R2A agar (Difco). To investigate basic physiological and biochemical characteristics, the methods of Smibert \& Krieg (1994) were used for the following tests: Gram staining, catalase, oxidase, indole production and hydrolysis of agar, casein, DNA and starch. Carboxymethylcellulose (Sigma) $(0 \cdot 1 \%)$ and Whatman powder CF11 $(0 \cdot 1 \%)$ were used for the cellulase test; hydrolysis of alginic acid $(0.5 \%, \mathrm{w} / \mathrm{v})$, chitin from crab shells $(1 \%, \mathrm{w} / \mathrm{v})$, pectin $(0.5 \%, \mathrm{w} / \mathrm{v})$ and tyrosine $(0.5 \%$, $\mathrm{w} / \mathrm{v}$ ) was also tested. Urease was determined as described by MacFaddin (2000). Flexirubin pigments were examined by the method of Fautz \& Reichenbach (1980). Congo red adsorption was tested by directly flooding colonies on agar plates with $0.01 \%$ aqueous Congo red solution. Motility was examined in $1 / 10$ strength R2A medium and gliding motility was observed by oil-immersion phase-contrast microscopy of the edge of colonies in exponential phase. Temperature tolerance was tested by growing cells at 5,10 , $15,20,25,30,33,35,37$ and $40^{\circ} \mathrm{C}$. Tolerance of different salinity levels was tested by growing cells in R2A broth supplemented with $0,1,2,3,5$ and $7 \%(\mathrm{w} / \mathrm{v}) \mathrm{NaCl}$. The $\mathrm{pH}$ range ( $\mathrm{pH} 4 \cdot 0-10 \cdot 0$ at intervals of $1 \cdot 0 \mathrm{pH}$ unit) for growth was determined in R2A broth that was buffered with citratephosphate or Tris/HCl buffers (Breznak \& Costilow, 1994). Tests in the commercial systems API 20NE, API 50CH, API ID 32 GN and API ZYM (bioMérieux) were generally performed according to the manufacturer's instructions in duplicate. The API ZYM tests were read after $4 \mathrm{~h}$ incubation at $37^{\circ} \mathrm{C}$ and the other API tests were read after at least $48 \mathrm{~h}$ at $28^{\circ} \mathrm{C}$.

Isoprenoid quinones were identified by an HPLC method as described previously (Groth et al., 1996). Fatty acid methyl esters were prepared and extracted from cells grown on R2A medium for $48 \mathrm{~h}$ at $28^{\circ} \mathrm{C}$, according to the standard protocol of the Microbial Identification System (MIDI; Microbial ID). The DNA G + C contents were determined according to Mesbah et al. (1989) using a reverse-phase column (Supelcosil LC-18-S; Supelco).

DNA-DNA hybridization was carried out as described by Seldin \& Dubnau (1985). Probe labelling was conducted using the non-radioactive DIG-High prime system (Roche) and hybridized DNA was visualized using the DIG luminescent detection kit (Roche). DNA-DNA relatedness was quantified using a densitometer (Bio-Rad).

The 16S rRNA gene sequence was determined by PCR amplification (Kwon et al., 2003) and direct sequencing (Hiraishi, 1992). A BLAST search (Altschul et al., 1997) revealed that the two novel isolates were closely related to several uncultured soil and marine bacterial clones. The $16 \mathrm{~S}$ rRNA gene sequences retrieved from GenBank were multiply aligned with those of the two novel isolates, approximately 1440 bases, using the program MEGALIGN (DNASTAR). The sequence similarity between the two novel strains was $98.9 \%$. The two strains showed highest sequence similarity (96.8 and $96 \cdot 3 \%$, respectively) to uncultured bacterial clone E26 (GenBank accession no. AM085477). The closest similarities among the type strains of all known species studied were obtained with Flexibacter japonensis IFO $16041^{\mathrm{T}}$ (GenBank accession no. AB078055; $91 \cdot 8$ and $91.9 \%$, respectively) and T. ferruginea ATCC $13524^{\mathrm{T}}$ (GenBank accession no. M62798; 90.4 and 90.6\%, respectively); sequences from other type strains showed $<90 \%$ sequence similarity. Phylogenetic and molecular evolutionary analyses were conducted using MEGA version 3.0 (Kumar et al., 2004), clustering was determined using the neighbourjoining and maximum-parsimony algorithms and bootstrap analysis (1000 replications) was made to determine the stability of the clusters. The neighbour-joining tree is shown in Fig. 1. A similar result (not shown) was obtained using the maximum-parsimony algorithm. The two novel isolates formed a cluster with three uncultured bacterial clones and T. ferruginea. The uncultured clones originated from a seasediment core (clone E26), soil (clone OF70; LaMontagne et al., 2003) and air (clone AKIW428). This cluster was related to another compact cluster that was composed of Flexibacter japonensis, Flexibacter sancti, Flexibacter filiformis and Chitinophaga pinensis. From the phylogenetic tree, it is clear the two novel isolates were affiliated with the phylum Bacteroidetes, but their phylogenetic position indicated that they were distinct from species with validly described names. Moreover, the strains clustered with several other species that are misclassified at the genus level (Nakagawa \& Yamasato, 1993; Sly et al., 1999). With their unique phylogenetic position shown in Fig. 1, considering the threshold value of $3 \% 16 \mathrm{~S}$ rRNA gene sequence difference to define a novel genus and species (Stackebrandt \& Goebel, 1994), the low similarity of the two novel isolates with respect to any other known bacterial species demonstrates that they represent a novel genus.

Both strains grew well on R2A and nutrient agar (NA; Difco), but did not grow on tryptic soy agar (TSA; Difco) or MacConkey agar (Difco). Cells of both strains were filamentous (Fig. 2), but lacked flagella (data not shown). Whereas strain GR20-10 $0^{\mathrm{T}}$ formed light-yellow-coloured colonies, those of strain GR20-13 ${ }^{\mathrm{T}}$ were milky-coloured. Colonies of both strains were irregular. In the API 50CH tests, neither isolate gave any positive reactions, except for aesculin hydrolysis. The phenotypic differences between the two novel strains and other related genera or species are summarized in Table 1. The differential phenotypic characteristics of GR20-10 $0^{\mathrm{T}}$, GR20-13 $3^{\mathrm{T}}$ and the most closely related species, T. ferruginea, are shown in Table 2. In the case of disparity between the results of conventional tests and API kit tests, conventional test results were recorded. The DNA-DNA hybridization value between GR20-10 ${ }^{\mathrm{T}}$ and GR20-13 ${ }^{\mathrm{T}}$ was $57 \%$.

The fatty acid profiles of GR20-10 ${ }^{\mathrm{T}}$ and GR20-13 ${ }^{\mathrm{T}}$ were very similar. The major fatty acids of both strains were $15: 0$ iso (26.8 and $30 \cdot 6 \%$ in GR20-10 ${ }^{\mathrm{T}}$ and GR20-13 ${ }^{\mathrm{T}}$, respectively), $17: 0$ iso $3-\mathrm{OH}(29 \cdot 4$ and $27 \cdot 1 \%)$ and $15: 1$ iso G (15.6 and 


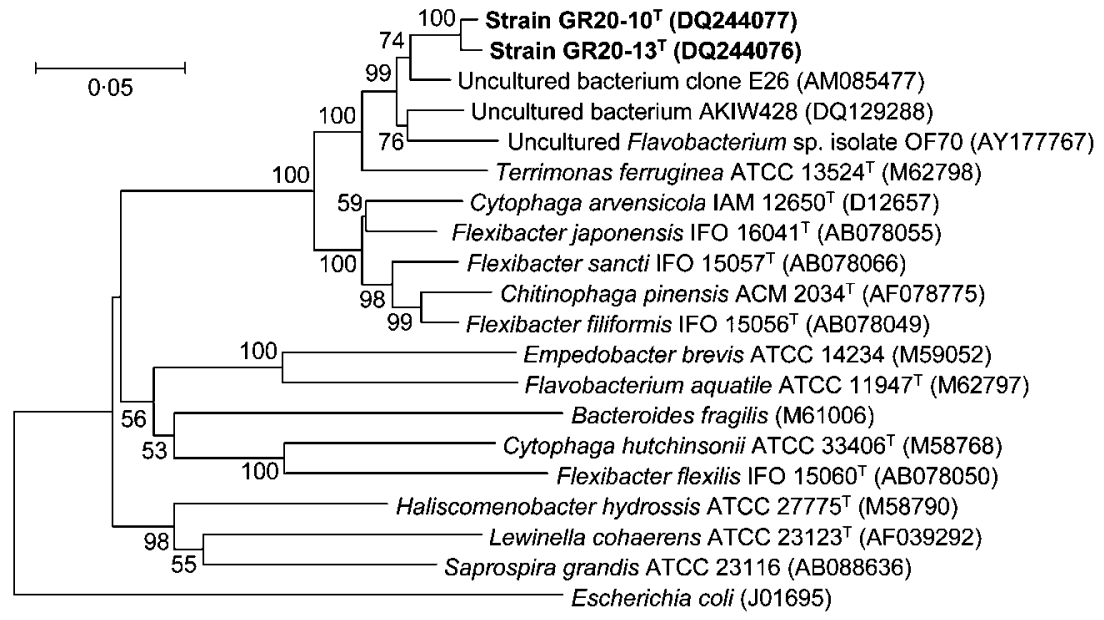

Fig. 1. Neighbour-joining tree showing the phylogenetic relationships of 16S rRNA gene sequences (Escherichia coli positions 501483) of strains GR20-10 $0^{\top}$ and GR20-13 ${ }^{\top}$ and their closest relatives in the DNA databases. E. coli (strain unknown) was used as an outgroup to root the tree. Numbers at nodes indicate levels of bootstrap support based on a neighbour-joining analysis of 1000 resampled datasets. Bootstrap values below $50 \%$ are not indicated. Bar, 5 substitutions per $100 \mathrm{nt}$.

$14 \cdot 7 \%$ ) (Table 3). T. ferruginea DSM $30193^{\mathrm{T}}$ could be differentiated from the two novel isolates by the presence of the unknown $13.565(4 \cdot 7 \%)$. The major isoprenoid quinone of both strains was MK-7. The DNA G $+\mathrm{C}$ contents of GR20-10 $0^{\mathrm{T}}$ and GR20-13 ${ }^{\mathrm{T}}$ were $45 \cdot 8$ and $44 \cdot 3 \mathrm{~mol} \%$, respectively.

On the basis of our results, it is proposed that isolates GR20-10 ${ }^{\mathrm{T}}$ and GR20-13 ${ }^{\mathrm{T}}$ represent two separate, novel species in a new genus, Niastella koreensis gen. nov., sp. nov. and Niastella yeongjuensis sp. nov., respectively.

\section{Description of Niastella gen. nov.}

Niastella (Ni.as.tel'la. L. dim. suff. -ella; N.L. fem. n. Niastella arbitrary name after NIAST, the National Institute of Agricultural Science and Technology, where taxonomic studies of this taxon were conducted).

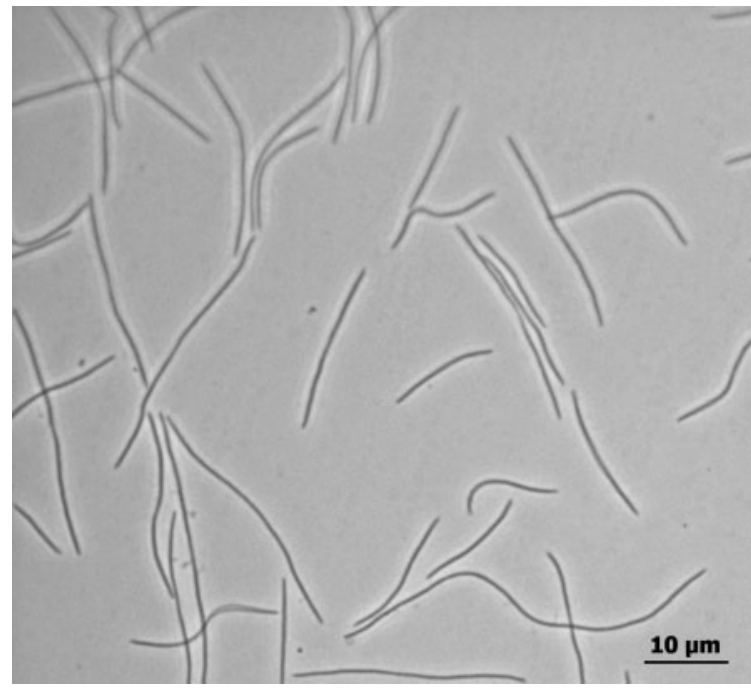

Fig. 2. Phase-contrast micrograph of cells of strain GR20-10 after growth for 2 days at $28^{\circ} \mathrm{C}$ on R2A medium. Bar, $10 \mu \mathrm{m}$.
Cells are Gram-negative, aerobic, non-flagellated, gliding and filamentous. Colonies are irregular. Grow on R2A and NA, but not on TSA or MacConkey agar. Flexirubin pigments are not formed, Congo red is not absorbed and nitrates are not reduced. Positive for hydrolysis of chitin, carboxymethylcellulose, casein, gelatin and tyrosine. Negative for hydrolysis of starch, agar, urea and DNA. Cellular fatty acids include large amounts of $15: 0$ iso, $17: 0$ iso $3-\mathrm{OH}$ and 15:1 iso G. The major respiratory quinone is MK-7. Phylogenetically, the genus Niastella is a member of the phylum Bacteroidetes. The type species is Niastella koreensis.

\section{Description of Niastella koreensis sp. nov.}

Niastella koreensis (ko.re.en'sis. N.L. fem. adj. koreensis of Korea, where the type strain was isolated).

Cells are $0 \cdot 4-0 \cdot 5 \mu \mathrm{m}$ in diameter and $10-50 \mu \mathrm{m}$ in length. Colonies are light yellow in colour on R2A. Growth occurs at $10-37^{\circ} \mathrm{C}$ and $\mathrm{pH} 5-8$. Physiological and biochemical properties are listed in Table 1 . The fatty acid profile is given in Table 3. Positive for aesculin hydrolysis and negative for nitrate reduction, indole production, glucose fermentation, arginine dihydrolase, urease and gelatin hydrolysis (API 20NE). Positive for alkaline phosphatase, leucine arylamidase, valine arylamidase, acid phosphatase, naphtholAS-BI-phosphohydrolase, $\beta$-galactosidase, $\alpha$-glucosidase, $\beta$-glucosidase and $N$-acetyl- $\beta$-glucosaminidase, weakly positive for cystine arylamidase and $\alpha$-galactosidase and negative for esterase (C4), esterase lipase (C8), lipase (C14), trypsin, $\alpha$-chymotrypsin, $\beta$-glucuronidase, $\alpha$-mannosidase and $\alpha$-fucosidase (API ZYM). None of the substrates included in API 20NE and API ID 32 GN (D-glucose, L-arabinose, D-mannose, D-mannitol, $\mathrm{N}$-acetylglucosamine, D-maltose, potassium gluconate, capric acid, adipic acid, malic acid, trisodium citrate, phenylacetic acid, L-rhamnose, D-ribose, inositol, sucrose, itaconic acid, suberic acid, sodium malonate, sodium acetate, lactic acid, L-alanine, potassium 5-ketogluconate, glycogen, 3-hydroxybenzoic acid, L-serine, salicin, D-melibiose, L-fucose, D-sorbitol, propionic acid, valeric acid, trisodium citrate, L-histidine, 
Table 1. Phenotypic properties of strains GR20-10 $0^{\top}$ and $G R 20-13^{\top}$ and related species

Taxa: 1, strain GR20-10 ${ }^{\mathrm{T}} ; 2$, strain GR20-13 ${ }^{\mathrm{T}} ; 3$, T. ferruginea DSM 30193 ${ }^{\mathrm{T}}$; 4, Chitinophaga pinensis; 5, Flexibacter japonensis; 6, Flexibacter filiformis; 7, Flexibacter sancti; 8, Cytophaga arvensicola; 9, Flavobacterium aquatile; 10, Flexibacter flexilis; 11, Cytophaga hutchinsonii. Data for T. ferruginea are from this study with the exception of the major menaquinone (from Xie \& Yokota, 2006) and G+C content (from Holmes et al., 1984). Data for other reference taxa are from Bernardet et al. (1996), Fujita et al. (1996), Holmes et al. (1984), Nakagawa \& Yamasato (1993), Reichenbach (1989a, b), Sangkhobol \& Skerman (1981), Sly et al. (1998), Vandamme et al. (1994) and Xie \& Yokota (2006). +, Positive; -, negative; W, weak reaction; V, variable among studies; ND, no data available.

\begin{tabular}{|c|c|c|c|c|c|c|c|c|c|c|c|}
\hline Characteristic & 1 & 2 & 3 & 4 & 5 & 6 & 7 & 8 & 9 & 10 & 11 \\
\hline Catalase/oxidase & $-1-$ & $-1+$ & $+{ }^{*} /+$ & $+1-$ & $+1+$ & $+1+$ & $-/ \mathrm{ND}$ & $+1+$ & $+1+$ & $-1+$ & $-1+$ \\
\hline Flexirubin reaction & - & - & - & ND & + & + & + & + & - & - & + \\
\hline Gliding motility & + & + & - & + & + & ND & ND & $\mathrm{V}$ & + & + & + \\
\hline Colony colour $\dagger$ & LY & M & OR & $\mathrm{Y}$ & OY & OY & GY & YO & LY & $\mathrm{O}$ & BY \\
\hline \multicolumn{12}{|l|}{ Hydrolysis of: } \\
\hline Starch & - & - & + & - & - & - & + & $\mathrm{V}$ & $\mathrm{V}$ & - & - \\
\hline Chitin & + & + & - & + & - & - & - & ND & - & - & - \\
\hline Carboxymethylcellulose & + & + & - & - & - & ND & + & ND & - & - & + \\
\hline Casein & + & + & - & + & - & - & ND & ND & + & - & $\mathrm{ND}$ \\
\hline Gelatin & + & + & + & + & + & $\mathrm{W}$ & + & $\mathrm{V}$ & $\mathrm{V}$ & + & + \\
\hline Urea & - & - & - & + & ND & ND & ND & - & - & ND & + \\
\hline DNA & - & - & - & - & + & + & ND & + & - & - & - \\
\hline Nitrate reduction & - & - & $-\ddagger$ & - & + & + & + & $\mathrm{V}$ & $\mathrm{V}$ & - & $\mathrm{ND}$ \\
\hline Major menaquinone & MK-7 & MK-7 & MK-7 & $\mathrm{ND}$ & MK-7 & MK-7 & MK-7 & MK-7 & MK-6 & $\mathrm{ND}$ & MK-7 \\
\hline $\mathrm{G}+\mathrm{C}$ content $(\mathrm{mol} \%)$ & $45 \cdot 8$ & $44 \cdot 3$ & $48 \cdot 6$ & $42-46$ & $49 \cdot 8$ & $46-47$ & $46-47$ & $43-46$ & 32 & $40-43$ & 40 \\
\hline
\end{tabular}

${ }^{\star}$ Reported as weak for strain IAM $15098^{\mathrm{T}}$ by Xie \& Yokota (2006).

$\dagger \mathrm{BY}$, Bright yellow; GY, golden yellow; LY, light yellow; M, milky; O, orange; OR, orange to red; OY, orange-yellow; Y, yellow; YO, yellow-orange. $\ddagger$ Reported as positive for strain IAM $15098^{\mathrm{T}}$ by Xie \& Yokota (2006).

Table 2. Differential phenotypic characteristics of strains GR20-10 $0^{\top}$ and GR20-13 ${ }^{\top}$ and T. ferruginea

Strains: 1, GR20-10 $; 2$, GR20-13 $;$ 3, T. ferruginea DSM $30193^{\mathrm{T}}$. All strains are positive for aesculin hydrolysis, alkaline phosphatase, leucine arylamidase, valine arylamidase, acid phosphatase, naphthol-AS-BI-phosphohydrolase and $N$-acetyl- $\beta$-glucosaminidase. All strains are negative for nitrate reduction, indole production, glucose fermentation, arginine dihydrolase, urease, esterase lipase (C8), lipase (C14), trypsin, $\beta$-glucuronidase and $\alpha$-fucosidase.

\begin{tabular}{|lccc|}
\hline Characteristic & $\mathbf{1}$ & $\mathbf{2}$ & $\mathbf{3}$ \\
\hline API 20NE & & & \\
Gelatin hydrolysis & - & + & + \\
API ZYM & & & \\
Esterase (C4) & - & - & + \\
Cystine arylamidase & $\mathrm{W}$ & $\mathrm{W}$ & + \\
$\alpha$-Chymotrypsin & - & + & - \\
$\alpha$-Galactosidase & $\mathrm{W}$ & $\mathrm{W}$ & - \\
$\beta$-Galactosidase & + & + & - \\
$\alpha$-Glucosidase & + & $\mathrm{W}$ & + \\
$\beta$-Glucosidase & + & $\mathrm{W}$ & $\mathrm{W}$ \\
$\alpha$-Mannosidase & - & - & $\mathrm{W}$ \\
\hline
\end{tabular}

${ }^{\star}$ Results were recorded after $48 \mathrm{~h}$ incubation.
Table 3. Cellular fatty acid composition (\%) of strains GR20-10 ${ }^{\top}$ and GR20-13 ${ }^{\top}$ and T. ferruginea

Strains: 1, GR20-10 ${ }^{\mathrm{T}}$; 2, GR20-13 ${ }^{\mathrm{T}} ; 3$, T. ferruginea DSM $30193^{\mathrm{T}}$. Only fatty acids that represent more than $1 \%$ of total fatty acids are indicated; -, not detected.

\begin{tabular}{|lccc|}
\hline Fatty acid & $\mathbf{1}$ & $\mathbf{2}$ & $\mathbf{3}$ \\
\hline $14: 0$ & - & - & $1 \cdot 4$ \\
$15: 0$ anteiso & $4 \cdot 9$ & $3 \cdot 3$ & $1 \cdot 6$ \\
$15: 0$ iso & $26 \cdot 8$ & $30 \cdot 6$ & $36 \cdot 5$ \\
$15: 0$ iso 3-OH & $1 \cdot 3$ & $1 \cdot 9$ & $2 \cdot 1$ \\
$15: 1$ iso G & $15 \cdot 6$ & $14 \cdot 7$ & $20 \cdot 7$ \\
$16: 0$ & $2 \cdot 6$ & $2 \cdot 9$ & $3 \cdot 8$ \\
$16: 0$ 3-OH & $1 \cdot 3$ & $2 \cdot 3$ & $1 \cdot 7$ \\
$16: 0$ iso & $1 \cdot 0$ & - & - \\
$16: 0$ iso 3-OH & - & - & $1 \cdot 0$ \\
$16: 1 \omega 5 c$ & - & $1 \cdot 2$ & - \\
$16: 1 \omega 7 c / 15: 0$ iso $2-\mathrm{OH}$ & $4 \cdot 3$ & $5 \cdot 3$ & $8 \cdot 2$ \\
$17: 0$ 2-OH & $3 \cdot 5$ & $2 \cdot 6$ & - \\
$17: 0$ 3-OH & $1 \cdot 2$ & - & - \\
$17: 0$ iso & $1 \cdot 6$ & - & - \\
$17: 0$ iso 3-OH & $29 \cdot 4$ & $27 \cdot 1$ & $11 \cdot 3$ \\
Unknown $13 \cdot 565$ & - & - & $4 \cdot 7$ \\
Unknown $16 \cdot 582$ & $1 \cdot 4$ & $1 \cdot 6$ & $1 \cdot 2$ \\
\end{tabular}


potassium 2-ketogluconate, 3-hydroxybutyric acid, 4hydroxybenzoic acid and L-proline) can be assimilated.

The type strain is GR20-10 $0^{\mathrm{T}}\left(=\mathrm{KACC} 11465^{\mathrm{T}}=\mathrm{DSM}\right.$ $17620^{\mathrm{T}}$ ), isolated from soil cultivated with Korean ginseng. The DNA G + C content of the type strain is $45 \cdot 8 \mathrm{~mol} \%$ (as determined by HPLC).

\section{Description of Niastella yeongjuensis sp. nov.}

Niastella yeongjuensis (ye.ong.ju.en'sis. N.L. fem. adj. yeongjuensis pertaining to Yeongju, a city in Korea, where the organism was first isolated).

Cells are $0 \cdot 4-0 \cdot 6 \mu \mathrm{m}$ in diameter and $10-40 \mu \mathrm{m}$ in length. Colonies are milky in colour on R2A. Growth occurs at 15$33^{\circ} \mathrm{C}$ and $\mathrm{pH} 5-8$. Physiological and biochemical properties are listed in Table 1 . The fatty acid profile is given in Table 3. Positive for aesculin hydrolysis and gelatin hydrolysis and negative for nitrate reduction, indole production, glucose fermentation, arginine dihydrolase and urease (API 20NE). Positive for alkaline phosphatase, leucine arylamidase, valine arylamidase, $\alpha$-chymotrypsin, acid phosphatase, naphthol-AS-BI-phosphohydrolase, $\beta$-galactosidase and $N$-acetyl- $\beta$-glucosaminidase, weakly positive for cystine arylamidase, $\alpha$-galactosidase, $\alpha$-glucosidase and $\beta$-glucosidase and negative for esterase (C4), esterase lipase (C8), lipase (C14), trypsin, $\beta$-glucuronidase, $\alpha$-mannosidase and $\alpha$-fucosidase (API ZYM). None of the substrates included in API 20NE and API ID 32 GN (see above) can be assimilated.

The type strain is GR20-13 ${ }^{\mathrm{T}}\left(=\mathrm{KACC} 11466^{\mathrm{T}}=\mathrm{DSM}\right.$ $\left.17621^{\mathrm{T}}\right)$, isolated from soil cultivated with Korean ginseng. The DNA G + C content of the type strain is $44 \cdot 3 \mathrm{~mol} \%$ (as determined by HPLC).

\section{References}

Altschul, S. F., Madden, T. L., Schaffer, A. A., Zhang, J., Zhang, Z. Miller, W. \& Lipman, D. J. (1997). Gapped BLAST and PSI-BLAST: a new generation of protein database search programs. Nucleic Acids Res 25, 3389-3402.

Bernardet, J. F., Segers, P., Vancanneyt, M., Berthe, F., Kersters, K. \& Vandamme, P. (1996). Cutting a Gordian knot: emended classification and description of the genus Flavobacterium, emended description of the family Flavobacteriaceae, and proposal of Flavobacterium hydatis nom. nov. (basonym, Cytophaga aquatilis Strohl and Tait 1978). Int J Syst Bacteriol 46, 128-148.

Breznak, J. A. \& Costilow, R. N. (1994). Physicochemical factors in growth. In Methods for General and Molecular Bacteriology, pp. 137-154. Edited by P. Gerhardt, R. G. E. Murray, W. A. Wood \& N. R. Krieg. Washington, DC: American Society for Microbiology.

Fautz, E. \& Reichenbach, H. (1980). A simple test for flexirubin-type pigments. FEMS Microbiol Lett 8, 87-91.

Fujita, T., Okamoto, M., Kosako, Y. \& Okuhara, M. (1996). Flexibacter japonensis sp. nov., a new species that produces a novel inhibitor of human leukocyte elastase isolated from soil. Curr Microbiol 33, 89-93.

Groth, I., Schumann, P., Weiss, N., Martin, K. \& Rainey, F. A. (1996). Agrococcus jenensis gen. nov., sp. nov., a new genus of actinomycetes with diaminobutyric acid in the cell wall. Int J Syst Bacteriol 46, 234-239.

Hiraishi, A. (1992). Direct automated sequencing of $16 \mathrm{~S}$ rDNA amplified by polymerase chain reaction from bacterial cultures without DNA purification. Lett Appl Microbiol 15, 210-213.

Holmes, B., Owen, R. J. \& McMeekin, T. A. (1984). Genus Flavobacterium Bergey, Harrison, Breed, Hammer and Huntoon 1923, $97^{\mathrm{AL}}$. In Bergey's Manual of Systematic Bacteriology, vol. 1, pp. 353-361. Edited by N. R. Krieg \& J. G. Holt. Baltimore: Williams \& Wilkins.

Kumar, S., Tamura, K. \& Nei, M. (2004). MEGA3: integrated software for molecular evolutionary genetics analysis and sequence alignment. Brief Bioinform 5, 150-163.

Kwon, S. W., Kim, J. S., Park, I. C., Yoon, S. H., Park, D. H., Lim, C. K. \& Go, S. J. (2003). Pseudomonas koreensis sp. nov., Pseudomonas umsongensis sp. nov. and Pseudomonas jinjuensis sp. nov., novel species from farm soils in Korea. Int J Syst Evol Microbiol 53, 21-27.

LaMontagne, M. G., Schimel, J. P. \& Holden, P. A. (2003). Comparison of subsurface and surface soil bacterial communities in California grassland as assessed by terminal restriction fragment length polymorphisms of PCR-amplified 16S rRNA genes. Microb Ecol 46, 216-227.

MacFaddin, J. F. (2000). Biochemical Tests for Identification of Medical Bacteria, 3rd edn, pp. 424-438. Baltimore: Lippincott Williams \& Wilkins.

Mesbah, M., Premachandran, U. \& Whitman, W. B. (1989). Precise measurement of the $\mathrm{G}+\mathrm{C}$ content of deoxyribonucleic acid by highperformance liquid chromatography. Int J Syst Bacteriol 39, 159-167.

Nakagawa, Y. \& Yamasato, K. (1993). Phylogenetic diversity of the genus Cytophaga revealed by $16 \mathrm{~S}$ rRNA sequencing and menaquinone analysis. J Gen Microbiol 139, 1155-1161.

Nakagawa, Y., Sakane, T., Suzuki, M. \& Hatano, K. (2002). Phylogenetic structure of the genera Flexibacter, Flexithrix, and Microscilla deduced from 16S rRNA sequence analysis. J Gen Appl Microbiol 48, 155-165.

Reichenbach, H. (1989a). Genus I. Cytophaga Winogradsky 1929, $577^{\mathrm{AL}}$ emend. In Bergey's Manual of Systematic Bacteriology, vol. 3, pp. 2015-2050. Edited by J. T. Staley, M. P. Bryant, N. Pfennig \& J. G. Holt. Baltimore: Williams \& Wilkins.

Reichenbach, H. (1989b). Genus Flexibacter Soriano 1945, $92^{\mathrm{AL}}$ emend. In Bergey's Manual of Systematic Bacteriology, vol. 3, pp. 2061-2071. Edited by J. T. Staley, M. P. Bryant, N. Pfennig \& J. G. Holt. Baltimore: Williams \& Wilkins.

Sangkhobol, V. \& Skerman, V. B. D. (1981). Chitinophaga, a new genus of chitinolytic myxobacteria. Int J Syst Bacteriol 31, 285-293.

Seldin, L. \& Dubnau, D. (1985). Deoxyribonucleic acid homology among Bacillus polymyxa, Bacillus macerans, Bacillus azotofixans, and other nitrogen-fixing Bacillus strains. Int J Syst Bacteriol 35, 151-154.

Sly, L. I., Taghavi, M. \& Fegan, M. (1998). Phylogenetic heterogeneity within the genus Herpetosiphon: transfer of the marine species Herpetosiphon cohaerens, Herpetosiphon nigricans and Herpetosiphon persicus to the genus Lewinella gen. nov. in the FlexibacterBacteroides-Cytophaga phylum. Int J Syst Bacteriol 48, 731-737.

Sly, L. I., Taghavi, M. \& Fegan, M. (1999). Phylogenetic position of Chitinophaga pinensis in the Flexibacter-Bacteroides-Cytophaga phylum. Int J Syst Bacteriol 49, 479-481.

Smibert, R. M. \& Krieg, N. R. (1994). Phenotypic characterization. In Methods for General and Molecular Bacteriology, pp. 607-654. Edited by P. Gerhardt, R. G. E. Murray, W. A. Wood \& N. R. Krieg. Washington, DC: American Society for Microbiology.

Stackebrandt, E. \& Goebel, B. M. (1994). Taxonomic note: a place for DNA-DNA reassociation and $16 \mathrm{~S}$ rRNA sequence analysis in the present species definition in bacteriology. Int J Syst Bacteriol 44, 846-849. 
Vandamme, P., Bernardet, J.-F., Segers, P., Kersters, K. \& Holmes, B. (1994). New perspectives in the classification of the flavobacteria: description of Chryseobacterium gen. nov., Bergeyella gen. nov., and Empedobacter nom. rev. Int J Syst Bacteriol 44, 827-831.
Xie, C. H. \& Yokota, A. (2006). Reclassification of [Flavobacterium] ferrugineum as Terrimonas ferruginea gen. nov., comb. nov., and description of Terrimonas lutea sp. nov., isolated from soil. Int J Syst Evol Microbiol 56, 1117-1121. 